\title{
Classification and quality criteria for Open Educational Resources in the field of foreign language learning
}

\author{
Zita Krajcso \\ University of Vienna, Austria \\ zita.krajcso@univie.ac.at
}

\begin{abstract}
Foreign language teachers use online repositories on everyday basis to find appropriate activities for their lessons. The question is: How can content providers support them in finding exactly what they need and in retrieving high quality resources?

This question has been discussed in the context of the European project "Open Discovery Space". The answers are: a taxonomy of searching mechanism and quality criteria of online resources from the methodologic point of view. Correspondingly, this paper introduces a classification of digital resources according to the four skills (speaking, writing, reading, listening/watching) and two language use types (grammar, vocabulary), representing the changing paradigm of foreign language teaching and learning. Further the paper identifies quality criteria for designing online learning materials with regard to content, methodology, technic and design. Finally, the findings are illustrated by an example of a learning scenario.
\end{abstract}

Keywords

e-learning, classification, quality criteria, OER, foreign language learning

\section{Introduction}

The Open Discovery Space ${ }^{1}$ Portal (ODSP) is one of the richest online repositories providing teaching material for education. The overall goal of the ODS project is to develop and implement a web-based access point where teachers can find educational resources made by others. Teachers can readily use these materials in their own classes, or adapt them to better match their particular educational context and the capabilities and learning styles of their students.

To successfully develop a purpose-built portal, the users and their needs and their expectations towards such a portal are the key to establish a sustainable pan-European ODS portal of educational resources (Laurillard, Oliver, Wasson, \& Hoppe, 2009).

One question is central to this issue: what do teachers need in order to uptake resource-based elearning? With this question in mind first we focus on the needs and expectations of teachers towards the ODSP.

In order to find out what teachers need for the adaptation of e-learning, stakeholders in the context of school education across Europe were invited to 92 workshops in 19 European countries. 2300 participants attended the workshops: school teachers (in-service or pre-service) of all education levels, teacher trainers, curriculum developers, and educational policy makers from local/regional/state level, students and parents participated.

The goal of the workshops was to build an initial contact with these stakeholders, to explore their teaching praxis and raise awareness of resource based learning (RBL). At the same time the visionary

1 Open Discovery Space is a European project funded by the Information and Communication Technologies Policy Support Programme (ICT-PSP). 
workshops aimed to gain their feedback, as well as their reflections and needs for the repository. The methodology of the survey followed a holistic approach: a questionnaire with multiple-choice and with open-ended questions was filled in by teachers and interviews were conducted. The survey and its detailed results can be found in separate papers (Clements, Krajcso, Moises, Lazonder, \& Pirkkalainen, 2013; Pirkkalainen 2013), within this article we outline only the most significant outcomes of the needs analysis.

First of all, teachers need high quality resources. Furthermore, the pool of resources must be big enough to offer something for many. The searching mechanism for the resources is also crucial; teachers need efficient ways for searching and finding materials (reached within three clicks) from different curricula backgrounds (classification by subject, topics and level).

The last requirement means that a portal should use a Controlled Vocabulary (via IEEE LOM) in order to ensure the effectiveness of information storage and resource search. A high quality controlled vocabulary will help the user to identify and locate desired educational content easily and though save time.

In the context of the ODS project, a suggested vocabulary covering all domains of the school education was developed. In this paper we focus on a vocabulary and quality criteria for OER (Open Educational Resources) in the field of language teaching.

\section{Classification theory}

In this context the design of language teaching methods include four components: learning and teaching environment, teacher, learner, and activity (including materials/resources). Resource-based learning is a view which gives prominence to the role of resources in the teaching and learning process.

The classification theory of language teaching activities determine different factors playing a role in their design and implementation: age of the learner, teaching approach, topic, form of cooperation, type of the activities, task, assessment, equipment, technical and other pre-requisites, etc. (Häussermann \& Piepho, 1996; Segermann, 1994; Neuner, Krüger, \& Grewer, 1981). Further classifications exist from the technical point of view (Felix, 2002; Rösler \& Ulrich, 2003; Tiutenko \& Koller, 2007; Westhofen, 2001), categorizing on-line activities: virtual classrooms, Hot Potatoes, WebQests, etc.

The classification theory lacks the user involvement and though remains to be the domain of experts rather than users. When teachers look for a learning activity for their teaching goal and specific target group, they want to find resources as quickly as possible, probably within three clicks (Clements et al., 2013; Pirkkalainen, 2013).

Considering the teachers' practice, it can be stated that practitioners search by learning activity type, topic and level, as these three factors seem to be the most informative and decisive. The rest of the factors build an additional information category (called advanced search) - but they are not a core for the first searching mechanism. For a better understanding, these three key factors are described in the following paragraph. The most recently and commonly used guideline which describes the achievement levels of foreign language learners is the Common European Framework of Reference for Languages (CEFRL), containing six levels: A1, A2, B1, B2, C1 and C2. The required topics depend on the institutional purpose (curricula), the goal of the whole class and also each and every individual taking part in the course; and can reach from everyday life themes to complex special issues.

The last category learning activity type is much more demanding, as the concept of language teaching has changed radically during the last years. Whereas in former days, it was mainly characterized by written grammar and translation exercises, nowadays more skill-oriented activities are prevalent (Bausch, Herbert, \& Krumm, 2003; DESI-Konsortium, 2008; Hinkel, 2006; Richards \& Renandy, 2002). This applies also for the context of school (Pinter, 2006). In the next chapter a complex classification of learning activities will be proposed. 


\section{Classification of learning activities}

According to the "new" paradigm of language teaching, language learning activities, exercises and tasks - independent from the language - can be classified as follows (see also Frimmel \& Krajcso, 2013a, 2013b; annex I. Language learning classification):

\section{- Skills}

○ Active skills

- Speaking

- Writing

- Passive skills

- Reading

- Listening and watching

\section{- Language use}

\section{- Grammar}

- Vocabulary

When teaching a foreign language in class, it is essential to foster all four skills mentioned above (speaking, writing, reading, listening and watching). For this purpose, it is important to subdivide these rubrics into pre-, during- and post-activities. Young, Hofer \& Harris (2011) explicitly suggest this subdivision only for the passive skill of reading and the active skill of writing. However, this subclassification makes sense for all four skills.

According to the paradigm transformation in language teaching theory language use activities (grammar and vocabulary) should be embedded in the activities of the skills. Here they build a separate element - as users are used to search materials with keywords grammar and vocabulary. Anyway they should be linked to the specific skill they refer to and in a later stage they could be completely integrated to the used skill.

The skills are subdivided into pre-, during- and post-activities (see also annex I. Language learning classification) At the beginning of a learning scenario, knowledge should always be activated or generated in some way, e.g. by brainstorming, researching, etc. This means that students can activate their prior knowledge or research a new topic before they start with the during-activity. Also information on the educational purposes and objectives should be part of the pre-activity, which helps learners in terms of focus and comprehension (Young et al., 2011). During-activities deal with new learning insights in a specific field of language learning. After the during-activity, a post-activity can involve a knowledge/competence deepening task (mainly active skills activities e.g. text production), a reflection sequence on the during-activity, e.g. students can discuss what has been dealt with in the during-activity with their peers, share content with other students, perform their finished work in class, etc. Also the evaluation of work and the assessment of goals' achievement can be a post-activity (Young et al., 2011).

\section{Quality theory}

Classification as such is crucial for the search mechanism, but quality factors determine the longterm successfulness of digital resources on the users' side (Ehlers, 2002; Lehmann \& Bloh, 2010). In the case of OER these factors relate to input (quality of the structure and potential), implementation (process) and output (outcome) aspects (Bloh, 2010, p. 18ff). In this paper I focus on the input quality criteria of OER and summarize the main results of the research in the context of language learning and teaching in order to determine quality characteristics for OER. Although building the basis for high quality learning scenarios, these criteria catalogue has not been proven as causal for the learning effect yet (Kerres \& Preußler, 2015, p. 46). More research is needed to confirm and extend the following quality criteria. 
By the categorization of OER quality requirements a user-friendly version is chosen (for a more complex one see e.g. Fey, 2015, p. 74ff). These traditional requirements refer to the following four main categories, which may partly overlap each other:

1. Content

2. Methodology

3. Design

4. Technic

In comparison to traditional learning objects digital resources should have an added value, which justifies the additional effort in design and which should be also transparent for the learner (Rösler \& Ulrich 2003:141, Kreidl 2011).

\section{Content}

Content deals with learning topics and subtopics and their educational appeals and the context of language learning. Characteristics of digital learning resources basically do not differ from traditional ones. The content must be chosen on the basis of:

1. context of learning (educational or professional context),

2. target group (its specific conditions, interests, knowledge, etc.),

3. educational purpose.

Following the literature in the field of language learning (Niehoff 2003:36, Westhoff, 2008, Meyer 2004, Bratengeyer \& Bubenzer \& Jäger \& Schwed 2015) the content display following aspects, here categorized in general characteristics, attitudes and knowledge factors.

\section{General characteristics}

- up-to date and/or updatable, but at the same time reusable,

- authentic,

- informative,

- factual correct,

- understandable, technical terms are explained,

- clear structured, coherent, complex issues are organized meaningfully and understandably, avoiding redundancies

- the sample of content is transparent and well founded

- links to background information for deepening knowledge and know-how are available

- dictionary / glossary / explanations are/may be integrated

\section{Attitudes}

- including educational appeal, stimulating learners to up-take attitudes,

- motivating, having a relevance for the learner, his/her attention is captured and maintained,

- polarizing meanings, generating tension, which is the basis for "authentic" interaction,

- vivid, including examples, novel, uncertain events and/or sense of humor,

- free from strong or mistakable stereotypes, meanings and positions, obscene and radical illustrations, etc.

\section{Knowledge/competence}

- linked to the learners' professional (e.g. curriculum, occupation) context, life and experiences, e.g. activate and recall prior knowledge,

- varied, include more than one perspective of a topic, motivating learners to decision making,

- besides information it includes also know-how (strategic competence) aspects,

- one step/level over the learners' knowledge regarding complexity of vocabulary. 


\section{Methodology}

Methodology refers to the didactical principles, learning theory and praxis, purposes and design of tasks and takes into account the up-to-date research in the disciplines psychology, sociology, education, linguistics and neurophysiology (Arnold, Koch-Priewe, \& Lin-Klitzing, 2007, p. 32ff).

In context of OER approved methodologic concepts remain valid, when ICT (Information and Communication Technology) is implemented as an instrument for a didactically meaningful purpose. The didactic concept is the most crucial aspect for the acceptance and success of the ICT implementation. According to literature (Niehoff, 2003; Meyer, 2004) the methodology is divided into goals, activities and tasks.

\section{Goals}

- oriented towards the learners' context,

- oriented towards the methodological variety,

- learner-centered (oriented towards the learners' interests, abilities, learning progress and other specific conditions),

- coherent and structured into main purposes and sub-goals,

- in a transparent way represented (purposes and benefits are recognizable), so that the learner is able to develop consciousness for the learning purpose,

- the achievement of goals is provable in some way.

\section{Activities}

- are clearly structured and coherent,

- oriented towards the methodological purpose and linked to the content,

- divided in pre- during- and post-activities (see chapter Classification of learning activities),

- foster decision-making, autonomous, critical and life-long learning processes,

- foster varied learning possibilities,

- foster not only individual work, but also interaction and communication if necessary,

- provide feedback, review, information on assessment, to foster the learners' acknowledgment.

\section{Tasks}

- varied, fostering the learners' intrinsic motivation,

- different levels of difficulty (at the beginning easy, later more complex),

- also the dimension of media competence is taken into account (competence of media critic, usage, design and publishing),

- clearly structured and coherent,

- also coherent (e.g. instructions follow nominal or verbal style, formal or informal form), correct terminology and free from failure,

- meaningful for the purpose and the learner,

- praxis and real-life oriented, realistic problem solving, fostering the acquisition of applicationoriented knowledge.

\section{Design}

Design involves all aspects we can sense with our organ of perception: visual and auditory issues (text, graphic, symbolic, color, background, picture, video, sound, etc.). High quality design reflects following characteristics (Frey, 2015; Niehoff, 2003):

- user-centric,

- appropriate and didactically meaningful chosen (oriented towards educational purposes, context, learners' specifications and content),

- functional, logic and focused,

- consistent, coherent and complementary, 
- integrated in a learning motivating way,

- ergonomic (e.g. color contrasts are pleasant),

- aesthetic (attractive to the learners),

- high-quality,

- is in any way harmful to anybody,

- the written or oral text is well readable, audible,

- appealing and clear layout.

\section{Technic}

In this paper the category of technic deals with the pedagogical view of learning systems, their functionalities and possibilities; and does not include implications to hard-, software or engineering issues.

The implementation of LMS (Learning Management System), media and tools should be oriented towards the methodology: goal, task, content, specification of the learner and the context. In case of elearning the didactical purpose is in the middle of attention and not technic or tools. The rule is: as much technic as necessary, and as little as possible. According to the literature (Salmon, 2004; Niehoff, 2003; Hemsing, 2015; Mikuszeit \& Szudra, 2009) the different technical arrangements work immaculate and fast and fulfil following prerequisites:

- functionality,

- intuitive usage, the user should feel a certainty by using ICT,

- support (information on different technical possibilities, user guidelines, contact),

- clear, consistent and user-friendly regarding structure, terminology of the tools and their use (e.g. navigation),

- continuity regarding learning objects, tools, LMS,

- user-friendly surface (as simple as possible),

- possibilities of individual, cooperative, synchrony and asynchrony learning/work on content (e.g. groupware),

- different communication channels (chat, mailing list, video conferencing, news-groups),

- possibilities for upload, store, edit, reuse and transfer of different learning materials,

- possibilities for learning assessment, automatic documentation of achieved goals.

These recommendations are crucial for ensuring quality criteria and simplifying searching mechanism, but how does a high quality learning scenario look like in real-life?

\section{Implementation to praxis}

For illustration reasons the resource portal Learn English of the British Council (see references) has been chosen. The example learning scenario presented in this paper is called "The Fridge". It is about a man who sends a Facebook friendship invitation to a woman who he met in a restaurant. However, before accepting his invitation, she first wants to get to know him better. Therefore, he invites her for dinner to his place and cooks lasagna for her.

This learning scenario involves a pre-, during- and a post-activity. In the pre-activity, vocabulary that is used in the during-activity, i.e. the film, is dealt with - words have to be matched with definitions. In the during-activity, the student watches a short film (the man who invites a woman for dinner tells the whole story outlined above). It is possible to have a look at the transcript of the film at any time during the whole learning scenario.

In the post-activity, the learner has to put given sentences in the correct order so that they describe the story presented in the film. Afterwards he/she has to indicate if given sentences about the film are true or false. Finally, the recipe of the lasagna the man has cooked is given. There is also a forum where people can discuss the film, the recipe, etc.

This learning scenario was chosen as an example because it illustrates how important it is to offer students a variety of activities, e.g. vocabulary exercise (pre-activity), watching a film (during-activity) 
and putting sentences in the correct order, true-false-exercise and discussion (post-activity). "The Fridge" also shows how different learning styles and paces can be coped with as students can take as much time as they need for completing the scenario, and moreover, it is possible to have a look at the transcript of the film at any time. This supports self-controlled learning and students' autonomy and may enhance the learning intensity.

Furthermore, this learning scenario is especially suitable for language teaching and learning purposes as learning processes and knowledge construction are focussed - students have to match words and definitions themselves. In addition it is functional and user-oriented, i.e. the learning scenario presents a useful result - here, the lasagna recipe is given, and, it fosters personal reflection and interaction - in the discussion forum, students can discuss the film, the recipe, etc.

From the content point of view this learning scenario is real-life-oriented because a recipe is given that can actually be tried by the students and because the discussion forum allows students to exchange their experience with the lasagna, the film, etc. Moreover, social activities on Facebook represent the starting point of the during-activity, which are an important part of young people's life. This makes it especially vivid and interesting for them to complete the learning scenario. Further the learning scenario "The Fridge" is up-to-date and authentic as it deals with getting to know new friends and adding them in Facebook - this attracts the students' attention. Furthermore, it is informative including background information like an explanation for the term "lasagne" and presents how a lasagna recipe can be tried by the students (representing know-how). Narrating the happenings by talking into the inside of fridge / to us - makes the monologue of the actor vivid and gives the learning scenario an unexpected plus.

The visual design of the learning scenario is simple and practical. The colours are reduced to grey and green and their shadows have a clean appearance. In addition they make a good detail contrast (e.g. by defining the content areas and dividing the activities into different sections) and match the websites' main colours. But, the typography - especially the font size - could be more consistent, gaining a more professional effect.

The technical realisation of the learning scenario is functional, the site works fast, the navigation bar is simple, it is clear what is clickable. The icons are transparent, understandable and make the activities easy to use. However, according to the postings some users have difficulties to play the video, but a link with a description is provided and technical support is given through the LearnEnglish Team. Anyway, the technical support/link should be placed more transparently, perhaps included in the right column in case of following the two-column layout meaningfully. The answers can be checked at the end of every activity and are also included in the pdf version of the learning scenario.

As far as the use of technologies is concerned in language learning, this example has shown that technology enhanced materials do have a lot of potential. Anyway it is challenging to design effective online resources for language teaching and learning purposes. Therefore content providers should take into account the quality catalogue and the classification - presented in this paper. Employing the principles offered in the corresponding chapters will help all stakeholders to ensure that their efforts are rewarded, ultimately, with satisfied users.

\section{Conclusion}

This paper described the outcomes of the ODS needs analysis carried out with 1175 participants from 19 European countries. According to the main findings of the needs analysis teachers have to be prevented from getting overwhelmed by the mass of resources that can be found in the World Wide Web. It is crucial to support them to find high quality resources and to retrieve easily what they need for their purposes. Accordingly recent research on classification and quality criteria for open educational resources has been described, and, a taxonomy and quality catalogue have been outlined. Furthermore, the outcomes of the paper were illustrated via a real-life learning activity. 


\section{Acknowledgment \& Permissions}

The research leading to these results has received funding from the European Union, Information and Communication Technologies Policy Support Programme (ICT-PSP) under grant agreement $\mathrm{n}^{\circ}$ 297229.

\section{References}

ARNOLD, K-H., KOCH-PRIEWE, B. \& LIN-KLITZING, S. (2007). Allgemeine Didaktik, Fachdidaktik und Unterrichtsqualität. In Arnold, K.-H. (Eds.), Unterrichtsqualität und Fachdidaktik (p. 19-49). Bad Heilbrunn: Klinkhardt.

BAUSCH, K., R., HERBERT, CH., \& KRUMM, H. J. (2003). Handbuch Fremdsprachenunterricht. Tübingen: Francke.

BLOH, E. (2010). Qualität und Evaluation metzbasierten Lehrens und Lernens. In Lehmann, B. \& Bloh, E. (Eds.), Online-Pädagogik. Band 4: Qualität und Evaluation (p. 7-143). Baltmannsweiler: Schneider.

BRATENGEYER, E., BUBENZER, A., JÄGER, J. \& SCHWED, G. (2015). eLearning Qualitäts-Evaluationstool. Books on Demand.

BRITISH COUNCIL (online). Learn English. Available at: http://learnenglish.britishcouncil.org.

CLEMENTS, K., KRAJCSO, Z., MOISES, M., LAZONDER, A. \& PIRKKALAINEN, H. (2013). A socially-driven content repository - Open Discovery Space Portal. In Proceedings The European Conference on Technology in the Classroom, 2013, 11-14 July, Brighton, England.

DESI-Konsortium (2008). Unterricht und Kompetenzerwerb in Deutsch und Englisch. Weinheim: Beltz.

EHLERS, U.-D. (2002). Qualität beim E-Learning: Der Lernende als Grundkategorie bei der Qualitätssicherung. In MedienPädagogik. Online-Zeitschrift für Theorie und Praxis der Medienbildung. Themenheft 1/2002. Lernsoftware - Qualitätsmaßstäbe, Angebot, Nutzung und Evaluation.

FELIX, U. (2002). Schritt halten mit dem Web: Die Aufgabe lösen. Available at: http://www.gfljournal.de/1-2002/felix.html - 30 July 2015.

FEY, C.-Ch. (2015). Kostenfreie Online-Lehrmittel. Eine kritische Qualitätsanalyse. Bad Heilbrunn: Verlag Julius Klinkhardt.

FRIMMEL, U. \& KRAJCSO, Z. (2013a). Classification of online resources in the field of language teaching, In Proceedings The European Conference on Language Learning, 2013, 18-21 July, Brighton, England.

FRIMMEL, U. \& KRAJCSO, Z. (2013b). Online Language Teaching Resources: Classification, Implementation and Guide, In Proceedings The Fourth International Conference on e-Learning (eLearning-2013), 26-27 September 2013, Belgrade, Serbia.

HÄUSSERMANN, U. \& PIEPHO, H-E. (1996). Aufgaben-Handbuch Deutsch als Fremdsprache: Abriß einer Aufgaben- und Übungstypologie. München: Iudicium.

HEMSING, S. (2015). Simply the best 10 Erfolgsfaktoren für gutes E-Learning. In Hamburger eLearningMagazin (Eds.), Was ist gutes eLearning? Qualität in Lehr-/Lernszenarien mit digitalen Medien.

HINKEL, E. (2006). Current Perspectives on Teaching the Four Skills. TESOL Quarterly, 40(1), 109-131.

KERRES, M. \& PREUßLER, A. (2015). Mediendidaktik. In Gross, F., Meister, D.M. \& Sander U. (Eds). Medienpädagogik - ein Überblick. Weinheim, Beltz Juventa.

KREIDL, C. (2011). Akzeptanz und Nutzung von E-Learning Elementen an Hochschulen. Münster: Waxmann.

LAURILLARD, D., OLIVER, M., WASSON, B. \& HOPPE, U. (2009). Implementing technology-enhanced learning. In Balacheff N., Ludvigsen S., De Jong T., Lazonder A. \& Barnes S. (Eds.), Technologyenhanced learning: Principles and products (p. 289-307). Springer: New York.

LEHMANN, B. \& BLOH, E. (2010). Online-Pädagogik. Band 4: Qualität und Evaluation. Baltmannsweiler: Schneider.

MEYER, H. (2004). Was ist guter Unterricht? Berlin: Cornelsen.

MIKUSZEIT, B. \& SZUDRA, U. (2009). Qualitätsanforderungen für didaktische Multimediaprodukte. In Mikuszeit, B. \& Szudra U. (Eds.), Multimedia und ethische Bildung. E-Learning - Ethik - Blended Learning (p. 195-222). Frankfurt/Main: Peter Lang. 
NEUNER, G., KRÜGER, M. \& GREWER, U. (1981). Übungstypologie zum kommunikativen Deutschunterricht. München: Langenscheidt.

NIEHOFF, M. (2003). Fremdsprachenlernen mit Multimedia. Anforderungen aus Sicht der NutzerInnen. Eine qualitative Untersuchung zum selbstorganisierten Lernen. Frankfurt/Main: Peter Lang.

PINTER, A. (2006). Teaching Young Language Learners. Oxford Handbooks for Language Teachers. Oxford: University Press.

PIRKKALAINEN, H., JOKINEN, J., PAWLOWSKI, J., \& RICHTER, T. (2014). Overcoming Cultural Distance in Social OER Environments. In Zvacek, S., Restivo, M., Uhomoibhi, J. \& Helfert M. (Eds.), CSEDU 2014: Proceedings of the 6th International Conference on Computer Supported Education: Vol. 1 (p. 15-24). SCITEPRESS Science and Technology Publications.

RICHARDS, J. \& RENANDY, W. (2002). Methodology in Language Teaching: An Anthology of Current Practice. Cambridge: University Press.

RÖSLER, D. \& ULRICH, S. (2003). Vorüberlegungen zu einer Übungs- und Aufgabentypologie für internetgestütztes Fremdsprachenlernen. In Legutke, M. \& Rösler, D. (Eds), Fremdsprachenlernen mit digitalen Medien. Tübingen: Gunter Narr Verlag.

SALMON, G. (2004). E-tivities. Der Schlüssel zu aktivem Online-Lernen. Zürich: orell füssli.

SEGERMANN, Ch. (1994). Typologie des fremdsprachlichen Übens. In Dortmunder Konzepte zur Fremdsprachendidaktik Band 1. Bochum: Brockmeyer.

TIUTENKO, A. \& KOLLER, G. (2007). Prinzipien einer sprachübergreifenden Typologie von Lern- und Testaufgaben für elektronische Sprachlehrwerke. In Klippel, F., Koller, G. \& Polleti, A. (Eds), Fremdsprachenlernen online. Münster: Waxmann.

WESTHOFEN, A. (2001). Typologie von WWW-Übungsmaterialien im Bereich Deutsch als Fremdsprache, Fachtagung lnternet im Unterricht Deutsch als Fremdsprache. Available at: http://www.editiondeutsch.de/tipps/vortrag-westhofen-uebungstypologie.pdf_- 30 July 2015.

WESTHOFF, G. (2008). Über die Lernwirksamkeit von Sprachlernaufgaben am Beispiel von "WebQuests". Fremdsprache Deutsch 38, 12-18.

YOUNG, CA., HOFER, M. \& HARRIS, J. (2011). Secondary English language arts learning activity types. Retrieved from College of William and Mary, School of Education, Learning Activity Types Wiki: available at: http://activitytypes.wmwikis.net/file/view/SecEngLangArtsLearningATs-Feb2011.pdf - 30 July 2015.

\section{Contact}

Dr. Zita Krajcso

Centre for Translation Studies / University of Vienna

Gymnasiumstraße 50.

A - 1190 Vienna

zita.krajcso@univie.ac.at 
Annex I. Language Learning Classification

\begin{tabular}{|c|c|c|}
\hline \multirow[t]{33}{*}{ Reading } & \multirow{2}{*}{$\begin{array}{l}\text { Pre-Reading } \\
\text { Activities }\end{array}$} & Activating / Generating knowledge \\
\hline & & Making predictions \\
\hline & \multirow{19}{*}{$\begin{array}{l}\text { During Reading } \\
\text { Activities }\end{array}$} & Aesthetic reading \\
\hline & & Analytical reading \\
\hline & & Authentic reading \\
\hline & & Consulting resources \\
\hline & & Content-oriented reading \\
\hline & & Detailed reading \\
\hline & & Directed / Guided reading \\
\hline & & Dramatic reading / Reader's theatre \\
\hline & & Global reading \\
\hline & & Independent reading \\
\hline & & Literature circles or book clubs \\
\hline & & Literature reading \\
\hline & & Literature study \\
\hline & & Nonfiction reading \\
\hline & & Orientating reading \\
\hline & & Reading other forms of text \\
\hline & & Rereading \\
\hline & & Selective reading \\
\hline & & Sustained silent reading \\
\hline & \multirow{12}{*}{$\begin{array}{l}\text { Post-Reading } \\
\text { Activities }\end{array}$} & Completing scales \\
\hline & & Creating text-related artifacts \\
\hline & & Critical analysis / Reflection \\
\hline & & Descriptive analysis \\
\hline & & Discussion \\
\hline & & Finding information gaps \\
\hline & & Making comparisons \\
\hline & & Quizzing / Testing \\
\hline & & Reading discussion \\
\hline & & Reconstituting / Reconsidering text \\
\hline & & Sharing / Collaborating \\
\hline & & Summarizing \\
\hline \multirow[t]{8}{*}{ Writing } & \multirow{8}{*}{$\begin{array}{l}\text { Pre-Writing } \\
\text { Activities }\end{array}$} & Brainstorming/Listing \\
\hline & & Choosing form / genre \\
\hline & & Doodling \\
\hline & & Higher-order webbing / Clustering \\
\hline & & Identifying purpose / audience \\
\hline & & Researching \\
\hline & & Sequencing / Outlining / Storyboarding \\
\hline & & Webbing / Clustering / Semantic mapping \\
\hline
\end{tabular}




\begin{tabular}{|c|c|c|}
\hline & \multirow{14}{*}{$\begin{array}{l}\text { During Writing } \\
\text { Activities }\end{array}$} & Conferencing \\
\hline & & Drafting \\
\hline & & Editing \\
\hline & & Establishing a coherence \\
\hline & & Free-writing / Guided free-writing \\
\hline & & Guided writing \\
\hline & & Note Taking \\
\hline & & Productive writing \\
\hline & & Revising \\
\hline & & Reproductive-productive writing \\
\hline & & Reproductive writing \\
\hline & & Writing Fiction \\
\hline & & Writing Nonfiction \\
\hline & & Writing Other Forms of Text \\
\hline & \multirow{4}{*}{$\begin{array}{l}\text { Post-Writing } \\
\text { Activities }\end{array}$} & Performing \\
\hline & & Presenting relevant information \\
\hline & & Publishing \\
\hline & & Sharing \\
\hline \multirow[t]{8}{*}{ Speaking } & $\begin{array}{l}\text { Pre-Speaking } \\
\text { activities }\end{array}$ & Activating knowledge \\
\hline & \multirow{6}{*}{$\begin{array}{ll}\text { During } & \text { Speaking } \\
\text { activities } & \end{array}$} & Discussing literary texts, culture and other topics \\
\hline & & Game tasks with different levels of complexity \\
\hline & & Instruction tasks \\
\hline & & Performance / Production \\
\hline & & Speaking / Speech \\
\hline & & Story telling \\
\hline & $\begin{array}{l}\text { Post-Speaking } \\
\text { activities }\end{array}$ & Evaluating / Criticizing Speech / Production \\
\hline \multirow{12}{*}{$\begin{array}{l}\text { Listening/ } \\
\text { Watching }\end{array}$} & \multirow{2}{*}{$\begin{array}{l}\text { Pre-Listening } \\
\text { activities }\end{array}$} & Activating / Generating Knowledge \\
\hline & & Brainstorming \\
\hline & \multirow{9}{*}{$\begin{array}{ll}\text { During } & \text { Listening } \\
\text { activities } & \end{array}$} & Analytical understanding \\
\hline & & Detailed listening \\
\hline & & Global listening \\
\hline & & Listening / Watching actively \\
\hline & & Listening / Watching passively \\
\hline & & Multimodal or multimedia interaction \\
\hline & & Recognizing \\
\hline & & Selective listening \\
\hline & & Understanding \\
\hline & $\begin{array}{l}\text { Post-Listening } \\
\text { activities }\end{array}$ & Evaluating \\
\hline
\end{tabular}




\begin{tabular}{|l|l|}
\hline \multirow{5}{*}{ Grammar } & Code Switching \\
\cline { 2 - 2 } & Explicit learning \\
\cline { 2 - 2 } & Implicit learning \\
\cline { 2 - 2 } & Mechanics \\
\cline { 2 - 2 } & Semantic Analysis \\
\cline { 2 - 2 } & Sentence Analysis \\
\cline { 2 - 2 } & Sentence Composing \\
\cline { 2 - 2 } & Style / Error Analysis \\
\cline { 2 - 2 } & Usage \\
\cline { 2 - 2 } & Word Analysis \\
\hline Vocabulary & Vocabulary Analysis \\
\cline { 2 - 2 } & Vocabulary Awareness \\
\cline { 2 - 2 } & Vocabulary Use \\
\hline
\end{tabular}

